\title{
Ecological observations associated with an anomalous warming event at the Houtman Abrolhos Islands, Western Australia
}
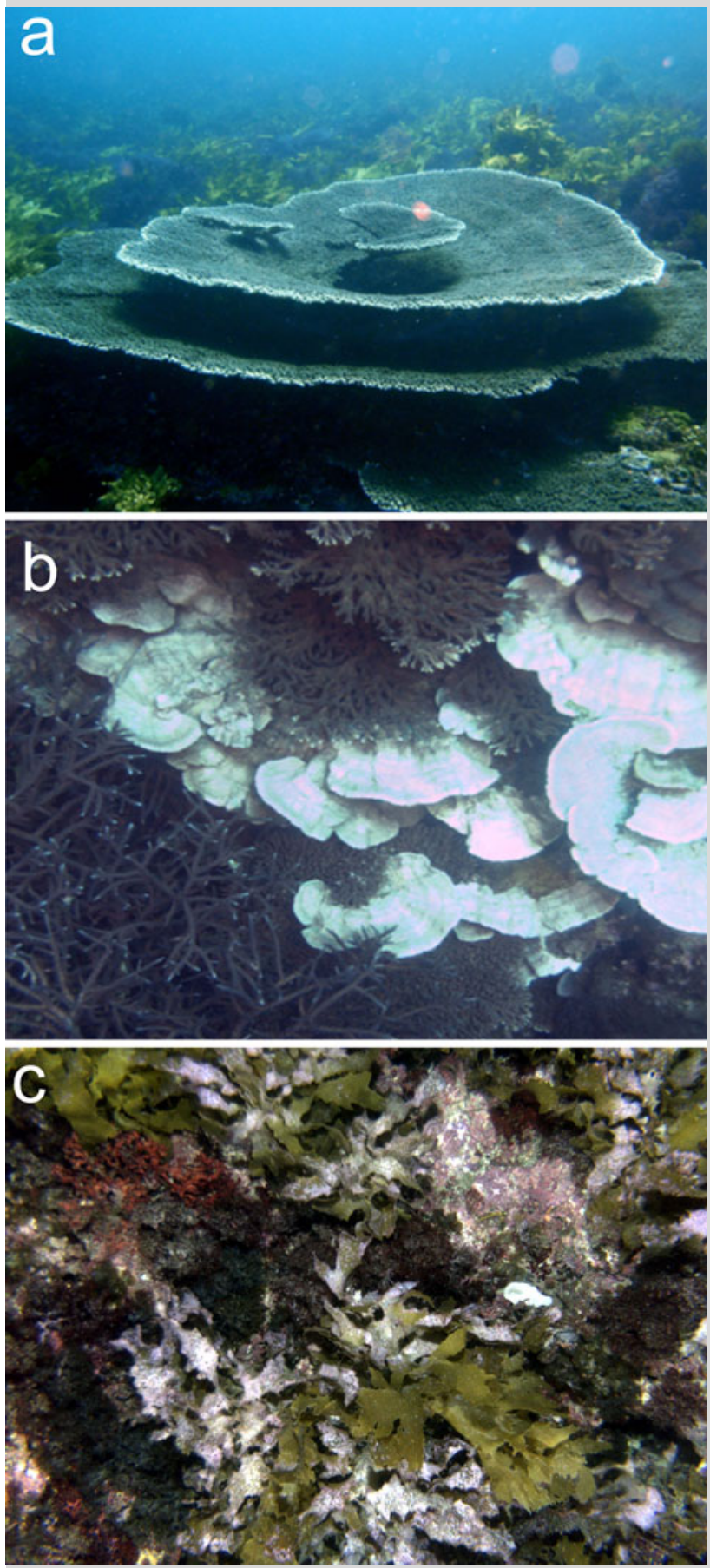

Fig. 1 a Massive plate coral (Acropora spicifera) thriving amidst dense kelp (Ecklonia radiata) at the Houtman Abrolhos Islands, b bleached coral, Montipora sp., and c heavy biofouling of Ecklonia radiata observed in April 2011
Coral reefs and kelp beds are two of the most ecologically and economically important marine habitats on Earth. Coral reefs and kelp beds are usually biogeographically distinct, being associated with tropical and temperate to subpolar areas, respectively. However, at the Houtman Abrolhos Islands $\left(28^{\circ} 43^{\prime} 0^{\prime \prime} \mathrm{S}, 113^{\circ} 47^{\prime} 0^{\prime \prime} \mathrm{E}\right)$, a group of small limestone protrusions some $60 \mathrm{~km}$ off Western Australia (WA), coral reefs and kelp beds are juxtaposed (Smale et al. 2010) (Fig. 1a). This unusual constellation is likely conditioned by the long environmental stability and unique oceanography of the region. The Houtman Abrolhos Islands experienced a marine 'heat wave' in 2011 driven, in part, by strong La Niña conditions, which increased the poleward flow of warm water along the coastline of WA (Pearce et al. 2011). Satellite-derived SSTs off WA were the highest on record during the event, while at the Houtman Abrolhos Islands temperature peaked at $28.7^{\circ} \mathrm{C}$ on March 1; $5^{\circ} \mathrm{C}$ higher than the long-term monthly mean (Pearce et al. 2011). Surveys of coral reefs and kelp beds $\left(>5,600 \mathrm{~m}^{2}\right)$ were conducted with an AUV in April 2011 at multiple sites, between 15 and $25 \mathrm{~m}$ depth. Image analysis revealed extensive bleaching (up to $20 \%$ of coral cover per site), primarily of Montipora spp (Fig. 1b). Widespread coral bleaching has not been reported from this system previously, even during exposure at spring tides and during the global bleaching event of 1998 (Webster et al. 2002), and no bleaching was observed in previous AUV surveys. Furthermore, extensive epibiosis of the kelp Ecklonia radiata (most likely by encrusting coralline algae) was observed adjacent to bleached coral (Fig. 1c), which has also not been reported before and may be associated with elevated temperatures. The islands represent a temperate-tropical transition zone, with many key species found at the edge of their ranges, so that marine communities here may act as important indicators of climatic change.

Acknowledgments We thank the Australian Research Council and the IMOS National reference station program for supporting this research.

\section{References}

Pearce A, Lenanton R, Jackson G, Moore J, Feng M, Gaughan D (2011) The "marine heat wave" off Western Australia during the summer of 2010/11. Fisheries Research Report No. 222. Department of Fisheries Western Australia, Perth

Smale DA, Kendrick GA, Waddington KI, Van Niel KP, Meeuwig JJ, Harvey ES (2010) Benthic assemblage composition on subtidal reefs along a latitudinal gradient in Western Australia. Estuar Coast Shelf Sci 86:83-92

Webster FJ, Dibden CJ, Weir KE, Chubb CF (2002) Towards an assessment of the natural and human use impacts on the marine environment of the Abrolhos Islands. Fisheries Research Report No. 134. Department of Fisheries WA, Perth, Australia

\section{A. Smale $(\bowtie) \cdot T$. Wernberg}

UWA Oceans Institute and School of Plant Biology (M096),

University of Western Australia, Crawley, WA 6009, Australia e-mail:daniel.smale@uwa.edu.au

\section{T. Wernberg}

Australian Institute of Marine Science, 39 Fairway, Crawley, WA 6009, Australia 